\title{
FORMULATING POLICY FOR A DEMOCRATIC SOUTH AFRICA: SOME OBSERVATIONS
}

\section{Tito Mboweni'}

\section{INTRODUCTION}

The primary mission of the African National Congress of South Africa (ANC) as stated on numerous occasions is the political economic and social emancipation of the majority of the people of South Africa, i.e. the Black people ${ }^{2}$. This mission statement in a real sense summarizes what the struggle against the apartheid system has been all about. It is important to remember, though, that this long-lived struggle against apartheid included the active participation of many of South Africa's White population. But giving content to this mission statement has demanded a great deal of work which was not really thought through or put together in detail. The process of detailed research seems to have been triggered off by a number of research projects since 1985 which sought to define more closely the character of the post-apartheid South Africa (PASA)

Formulating economic policy has been one of the most difficult and challenging tasks confronting the democratic forces. 'Getting the economy right' is crucial to South Africa's future social and political stability, as well as to meeting the reservoir of untapped basic needs of much of our population.

The policy process in the ANC has a number of layers which if not properly understood, can lead to major errors of judgement and analysis. These layers can be summarized as follows: the constitu tional structures; the policy departments; the positions of the allies of the ANC (in particular COSATU); the expe riences of developing countries; the lobbying efforts of capital, the media, western governments, and independent commentators; and policy research work of the IMF and World Bank.

The key layers are those of the ANC constitutional structures, the work of the policy departments and the policy positions of the Alliance partners. However, experience in other countries shows that the role of other forces, particularly the business sector, the IMF and World Bank cannot be underestimated.

\section{THE CONSTITUTIONAL STRUCTURES}

The elected bodies of the ANC compose the important constitutional structures. The highest policy making body in the ANC is the National Conference which is convened every three years. In between these National Conferences, the National Executive Committee (NEC) is the highest policy making body. Further, the National Working Committee (NWC) or the ANC 'Cabinet' as it is referred to by other people, can also make policies in between the meetings of the NEC. ${ }^{4}$

Therefore only recommendations endorsed by these structures can be considered as constituting ANC policy. The media in particular has misunderstood this fact. From time to time they refer to statements
1 Tito Mboweni is Deputy Head of the Department of Economic Planning, ANC. These are his personal observations and do not represent the views of either the ANC or the Department of Economic Planning.

2 'Black' refers to the African, Coloured and Indian peoples in South Africa.

${ }^{3}$ Numerous conferences and seminars began to mushroom about 1985 looking at PASA. Some of the most prominent ones were the York University Conference (1986) and the Lausanne Colloquium (1989). Research centres were also started during the same period, e.g. the Centre for DevelopmentStudies (CDS) and theSouth African Research project (SASPRO).
4 The NEC is elected by National Conference for a term of three years. The NEC at its first meeting, elects a smaller National Working Committee which runs the day to day affairs of the ANC. Theoretically, every department in the ANC should be headed by a member of the NWC. These heads of department are also supposed to meet regularly with the Secretary General. The full meetings of the NWC take place every week and are attended by the officials as well. The officials are the President, Deputy President, National Chairman, Secretary General, Deputy Secretary General and the Treasurer General. 
by individual members of the ANC as policy. Granted one would expect that when people in official positions speak, they should be reflecting official positions, but this has not always been the case $\mathrm{e}^{5}$. This confusion between official policy and policy issues contained in an individual's speech or paper, has resulted in what people within the ranks have called making policy on the hoof! This often leads to some confusion regarding ANC policy.

Thus it is important to underscore that policy is made by the constitutional structures of the ANC and no individual has any constitutional right to make policy on the hoof for the organization.

\section{POLICY DEPARTMENTS}

There are a number of policy departments in the ANC. Amongst these are: Economic Planning, Health, Human Resources Development, Local Government and Housing, Arts and Culture, Education and Social Welfare. Whilst these are policy departments, they do not make policy but can only develop policy recommendations which they submit to National Conference, the NEC and NWC for consideration. There can be no doubt though that what these departments recommend does carry a lot of weight. But it would be a mistake once again to think that what these departments say or have developed, is by definition ANC policy. Many people also make the mistake of elevating policy departments to policy-making structures.

The Department of Economic Planning for one, is probably one of the most active departments in the ANC. It has a number of divisions such as trade and industry, science and technology, land and agriculture, minerals and energy, and fiscal and monetary policy. It is also responsible for the following policy areas: transport, environment, development planning, labour markets, regional policy in southern Africa, public corporations, and monitoring and analysis of IMF and World Bank research and policies.

The DEP, accordingly has a political head who is a member of the NWC and is staffed by a team of economists and other relevant policy development and analysis coordinators. The Department is linked to a number of researchers who are based at several centres around South Africa and abroad. The most well known research facility for the DEP is the Macroeconomic Research Group (MERG). But the DEP also related to and benefits from the work of the Industrial Strategy Project $(\text { ISP })^{6}$ and other work of the anti-apartheid economics community.

In practice, it means that every DEP division works in close collaboration with a research network. For example, the trade and industry division would work with the ISP, COSATU and other economists and industrial sociologists working in this area. The system does not always work that well, but it has proved to be a very useful and productive mechanism for incorporating democratically minded economists and researchers into our policy work.

The DEP has to process all the research material and arrange it in a policy framework. This is not easy and requires a combination of technical skills and political experience. At the end of the day, responsibility for any policy positions proposed for consideration by the constitutional structures rests with DEP in relation to economic policy. Once again the process can be very difficult and frustrating.

\section{POLICY POSITIONS OF ALLIES}

One of the principal allies of the ANC in South Africa has been the Congress of South African Trade Unions (COSATU). COSATU's overall policy thrust is guided by their strategic vision of
${ }^{5}$ This issue gets to the central unresolved difficulty of when is an official's opinion private and when is it official. There are some officials in the movements who have been able to defend their right to have a private opinion yet others have failed to doso. In general though, if one states that one is not speaking or writing in an official capacity, that should be sufficient to indicate thestatus of one's position. For example, the views in this article are my personal views and can in no sense be constituted as representing the views of my colleagues, the DEP in the ANC.
6 The ISP is a research project of the Economic Trends Group (ET). The project was undertaken in collaboration with COSATU and later the ANC also began to be involved with the project. An impressive number of research papers is currently being processed. See elsewhere in this Bulletin for an initial summary of their analysis and policy conclusions. 
building socialism in South Africa. The ANC, on the other hand, is a multi-class based national liberation movement whose central thrust is the building of a democratic, non-racial society which brings together the various classes within the context of a mixed economy and socio-economic development. The objectives of these principal allies may seem to sit rather uncomfortably with one another and this could be expected to cause some serious ideological differences and tensions between the ANC and COSATU.

COSATU accepts that the task of the ANC is not to build socialism, but to create a truly democratic society in which the different ideological positions can be debated and around which organizations can be built in pursuance of their objectives without state hindrances. It is also critica 1 to understand that COSATU is a trade union federation and not a political party. Tensions are inevitable between the ANC and COSATU and such tensions must be expected to come to the fore in the coming months and years. Be that as it may, COSATU has played an important role in counterbalancing whatever influence there may be on the ANC from capital, the IMF, the World Bank and western governments.

\section{EXPERIENCES FROM OTHER DEVELOPING COUNTRIES}

In general, the ANC takes the experience of other countries very seriously in the policy development work. The fact that many ANC cadres lived and worked in many of these countries during their years in exile has also enriched this process tremendously. Obviously, in their research work, most of the researchers do comparative analysis with other developing, newly industrialized and developed countries as well. The accusations by sections of capital and also by some ANC detractors that the ANC has not learnt anything from international experience is simply not true. However, there are lessons and 'lessons' in real life since people draw different conclusions from the same experiences.

In addition, the ANC research networks include experienced researchers from North America (with Latin American and developing country experiences), the UK, the African continent and India. These connections have played an important part in ensuring that policy is not ignorant of interna- tional experiences as well. Most importantly though, some of these international researchers have been valuable in pinpointing, fairly early on in the policy process, some major gaps and errors awaiting a new democratic government.

\section{THE ROLE OF CAPITAL, THE MEDIA, COMMENTATORS AND WESTERN GOVERNMENTS}

Capital, both domestic and international, sees itself as being the party likely to lose the most when a democratic South Africa becomes a reality. The reasons for this are not hard to find. None of them are unaware of the historically interconnected, almost umbilical connections between the apartheid state, racism and capital in South Africa. Their fear is that in post-apartheid South Africa, at least two critical elements of the above equation will be deleted. These elements are racism and the apartheid state. In many cases the business community tends to see these developments as anti-capital since the movement has indicated it is committed to such policies as affirmative action, antitrust actions, industrial restructuring, a wage-skills nexus, and others. Even though nationalism no longer features on top of the agenda for the ANC, it does for COSATU and this is seen as yet another threat to business.

Given the above perceptions and concerns, capital has decided to go on the offensive through its media and also by directly appealing to various elements within the ANC. Lunches, dinners and receptions are being organized on a regular basis. In addition weekend outings are taking place with what capital considers to be 'influential' ANC policy makers. Indeed, there are very few, if any, within the policy departments of the NEC and NWC who have not been invited to these functions and outings. There have also been numerous offers of (free!) technical assistance to the movement by capital.

One of the most dramatic policy interventions by capital was, in my view, when the chairman of an international oil and industrial conglomerate hired a private jet and came to South Africa to speak to the president of the ANC to persuade the ANC leadership that nationalization was a doomed policy! Unfortunately for him the president was too busy to attend this meeting. 
The media in South Africa, as in many other countries, plays a major role, albeit an indirect one, in the policy formulation process. An example in this regard could be the media treatment of nationalization as propagated by the ANC president, Nelson Mandela. In what looked like a coordinated media offensive, Mandela was attacked and criticized on a regular basis until he began to show some flexibility on the issue. Similarly, I have been hammered by the media for daring to suggest that a reconstruction levy should be introduced as part of the financing of socio-economic development in the post-apartheid period ${ }^{7}$. The media's success in my case is clearly illustrated by the unwillingness of the ANC leadership to touch the issue of a reconstruction levy.

There are many other examples of how the media has influenced certain decisions and yet they are not accountable to the constitutional structures of the ANC. Sometimes the media pushes though certain policies to be made on the hoof by deliberately asking prominent leadership questions in situations where an answer has to be given. This has often led to policies being 'announced' which have actually never been thoroughly researched or discussed in the movement. In the process, the media generates a host of sometimes contradictory policy pronouncements from amongst the leadership. This is by far one of the most dangerous tendencies in the media which is likely to intensify when a democratic government (with many Black faces!) comes into office. The objective would be to show that such a new government does not know what it is doing.

It is easy to say that one should not bother to reply to deliberately provocative questions from the media. But that is more easily said than done.

Closely related to the media is the role of the socalled independent commentators whose opinions seem to be generally valued more than those of the policy spokespersons of the ANC. Usually journalists in South Africa use phrases such as 'experts say', or this or that commentator said.

7 Mboweni, $T$ ' "Burden sharing" the way', in The Star (Johannesburg), June 30 1993. Some of the responses were: 'Call it a reconstruction levy wealth tax, or what you will, the idea would amount to redistribution through government extracting more money from the overburdened formal sector of the economy ... Redistribution is necessary but can only be achieved successfully by boosting
In some cases, some people are actually being quoted but in many instances, no-one is quoted. Thus the media create their own 'expert commentators'.

In situations where these commentators do comment, they are usually opposed to what the movement is saying. By so doing, they construct a widespread view which makes the movement's position look foolish and not worth implementing. There are instances as well where some of our people have retreated very fast from difficult policy positions as a result of what commentators and media have said about a specific policy issue. But, it is instructive that in the majority of cases the movement has ridden the storm and stuck to the policy regardless.

The diplomatic representation in South Africa of western governments has been a key centre of policy intervention by these countries. Normally the ambassador or the consular general arranges receptions and dinners at which policy issues are debated at length and sometimes things like 'my government thinks that your policy on this or that is dangerous' or 'we suggest that you drop this or that policy and try our example' and so on. At times, some of these diplomats organize closed seminars in which policy issues are discussed and the 'ill advised' policies of the democratic movement are said to be bad for business and economic growth (never mind redistribution!).

There are also instances where visiting ministers sometimes - I think - overstep their diplomatic courtesy and lecture the movement leadership on policy issues. For some reason, these ministers or delegations are confident that they can change the views of the movement with this kind of pressure. At times, encounters such as this are used by these ministers to argue the case for capital's agenda. And it is all presented in a supposedly non-ideological basis of 'support' for the movement! Many of these politicians seem to forget that sometimes they used to be the

productivity and investment, by building confidence in the market economy' 'Taxing idea',The Cape Times (editorial). The Finance Week editorial said: 'Allow (Mboweni) his way and there won' tbe sufficient businessmen with R500 to lavish on messages of reassurance at his leader's future birthday parties'. 
major opponents of the movement during the difficult days of apartheid. Now they are all so friendly and determined to protect certain policy approaches.

\section{THE IMF AND THE WORLD BANK}

As elsewhere in the developing world, the IMF and the World Bank are also determined to influence the policy agenda in South Africa. The IMF visits South Africa every year in terms of Article IV requirements. In our experience, the Fund is far more rigid and deals only with the ancien régime. Their Article IV papers are highly influencial in government policy circles but they remain uninfluential in the democratic movement since they are not officially made available to $\mathbf{u s}^{8}$.

The World Bank has begun to work on some South Africa research since 1990 . In contrast to the IMF, the Bank's approach has bee $\mathrm{n}$ different. It has decided to work very closely with the democratic movement in their research programme. In the process it has engaged South African researchers associated with the movement. These researchers have always retained their righ $t$ to dissociate themselves with the final conclusions of the Bank in case these prove to be in conflict with research findings.

The Bank's research results have made a big impact in South Africa'. Although many of us are very critical of the Bank's general policy approach, some of their research reports have been well researched and are of a high technical quality. However, it is to soon to tell how their policy proposals will be treated by an incoming democratic movement. In general, the movement is highly sceptical of the record of the Bank and Fund with respect to their structural adjustment programmes. But the multilateral institution have been astute, and they have not as yet really suggested policy along the traditional lines. Thus some of their work, as in the Belli Report on Trade (1993), have been well regarded by a wide range of forces.

\section{BURGERS IN THE POLICY SANDWICH}

At times those of us working in policy departments have felt like burgers in the policy sandwich. At the rational level, we want policy to be developed from research and be influenced by the political positions of the movement. However, the 'policy noises' created by all the forces discussed above can make life very uncomfortable. And there is nothing as frustrating as working on a policy recommendation which is not accepted by the constitutional structures; worse still is to work on something which in all respects makes good policy for transformation but only to have the movement shy away from it due to external pressures. The danger in such situations is that policy begins to lack internal consistency and could become a collection of lowest common denominator interests. Yet there is a feeling of internal fulfilment and joy when Conference or other policy structures of the movement adopt - albeit with amendments certain policy recommendations put forward by the policy departments.

The conclusion drawn from the South African experience so far illustrates the importance of balancing the various interest of the competing forces with one's political or if I may use the term, ideological position. There are certain essential principles which the movement should never compromise upon if it is to remain the vehicle for the political, social and economic transformation of South Africa and by so doing to improve the standard of living for the majority of Black people.
8 The only IMF document which gained some prominence in South Africa was published in 1992. Lauchman, D. et al: Economic Policies for new South Africa.
9 Two examples are Fallon P. et al, 1993: South Africa, Economic Performance and Some Policy Implications (Washington: The World Bank) and Belli, P., Finger, M., and Ballivan, A., 1993: South Africa, A Review of Trade Policies (Washington: The World Bank). 